\title{
AUTENTIKASI PRODUK OLAHAN IKAN HIU KOMERSIAL MENGGUNAKAN TEKNIK SPECIES-SPECIFIC DNA Mini-barcodes
}

\author{
Asadatun Abdullah ${ }^{1 *}$, Ari Elisa Ratih ${ }^{1}$, Shabrina Aulia ${ }^{1}$, Puji Rianti ${ }^{2}$, Tati Nurhayati ${ }^{1}$, \\ Agoes Mardiono Jacoeb ${ }^{1}$ \\ ${ }^{1}$ Departemen Teknologi Hasil Perikanan, Fakultas Perikanan dan Ilmu Kelautan, IPB University. Gedung \\ FPIK Lantai 3, Jalan Lingkar Kampus IPB Dramaga Kabupaten Bogor Jawa Barat Indonesia 16680 \\ ${ }^{2}$ Departemen Biologi, Fakultas Matematika dan Ilmu Pengetahuan Alam, IPB University \\ ${ }^{*}$ Korespondensi: asabdullah@apps.ipb.ac.id \\ Diterima: 20 Juli 2020/ Disetujui: 31 Agustus 2020
}

Cara sitasi: Abdullah A, Ratih AE, Aulia S, Rianti P, Nurhayati T, Jacoeb AM. 2020. Autentikasi produk olahan ikan hiu komersial menggunakan teknik species-specific DNA Mini-barcodes. Jurnal Pengolahan Hasil Perikanan Indonesia. 23(2): 383-391.

\begin{abstract}
ABSTRAK
Pemanfaatan ikan hiu sebagai bahan baku produk olahan perikanan dapat menyebabkan berkurangnya populasi ikan hiu yang juga rentan akan kepunahan. Ikan hiu pada umumnya diperdagangkan dalam bentuk sirip, daging ikan yang diasinkan dan direbus, minyak ikan serta sebagai bahan subtitusi pada pakan hewan sehingga proses identifikasi menggunakan metode berbasis morfologi dan meristik sulit dilakukan. Sebagai alternatif proses autentikasi bahan baku produk olahan ikan hiu adalah menggunakan teknik DNA mini barcodes. Penelitian ini bertujuan untuk merancang dan mengaplikasikan primer DNA mini barcodes yang spesifik terhadap tiga species hiu terancam punah yang masuk dalam daftar CITES (Sphyrna lewini, Alopias pelagicus, Carcharhinus falciformis) serta mengaplikasikan pada berbagai produk olahan ikan hiu. Tahapan penelitian yang dilakukan meliputi koleksi sampel produk olahan perikanan, perancangan primer spesifik, isolasi DNA, pengujian kualitas dan kuantitas DNA, amplifikasi DNA, dan sekuensing. Berbagai produk olahan komersial berhasil diamplifikasi oleh primer spesifik yaitu pada target $300 \mathrm{pb}$ (S. lewini), 285 $\mathrm{pb}$ (A. pelagicus) dan $352 \mathrm{pb}$ (C. falciformes). Hasil sekuensing DNA sampel menunjukkan bahwa spesies teridentifikasi adalah S. lewini, A. pelagicus, C. falciformes dan Hemigaleus microstoma dengan kemiripan 99-100\%. Hal tersebut menunjukkan bahwa masih terdapatnya pemanfaatan ikan hiu yang dilindungi secara ilegal, sehingga perlu penerapan regulasi yang lebih ketat untuk melestarikan spesies-spesies hiu yang terancam kepunahannya.
\end{abstract}

Kata kunci: Alopias pelagicus, Carcharinus falciformis, CITES, DNA mini-barcodes, Sphyrna lewini

\section{Authentication of Commercially Shark Products Using Species-Specific DNA Mini-barcodes Techniques}

\begin{abstract}
The use of shark for processed fishery products raw material may threat the vulnerable shark population to extinction. Sharks generally traded in the form of: fins, salted and boiled fish meat, fish oil and for animal feed, therefore, the identification process using morphology and meristic based methods are challenging. An alternative to the process of seafood labelling authentication, the DNA mini barcodes technique could be applied. This study was aimed to design and apply species-specific DNA mini barcodes primers of three endangered shark species that are included in the CITES list (Sphyrna lewini, Alopias pelagicus, Carcharhinus falciformis) as well as applying it into various commercial processed shark products. The research methods were started with collection of processed fishery product samples, designing species-specific primers, DNA isolation, testing the quality and quantity of DNA, DNA amplification, and sequencing. Various commercial products were successfully amplified by species-specific primers, namely the target of $300 \mathrm{bp}$ (S. lewini), $285 \mathrm{bp}$ (A. pelagicus) and $352 \mathrm{bp}$ (C. falciformes). The sequencing results demonstrated the identified species as S. lewini, A. pelagicus, C. falciformes and Hemigaleus microstoma with homology of 99$100 \%$. The results showed that the illegal application of sharks, thus it is necessary to apply more stringent regulations to conserve shark species that have been threatened with extinction.
\end{abstract}

Keywords: Alopias pelagicus, Carcharinus falciformis, CITES, DNA mini-barcodes, Sphyrna lewini 


\section{Pendahuluan}

Produk olahan perikanan pada umumnya dapat diperoleh di pasar komersial dalam bentuk fillet yang dibekukan, pangan siap saji, suplemen maupun aksesoris kerajinan. Ikan hiu dan pari merupakan salah satu bahan baku yang cukup banyak digunakan di Indonesia sebagai sumber protein maupun sebagai hiasan. Salah satu produk perikanan bernilai komersial sangat tinggi adalah sup sirip ikan hiu. Sup dari sirip ikan hiu ini menjadi salah satu makanan seafood khas Asia Timur yang paling mahal (Wallace et al. 2012). Selain sebagai bahan baku sup sirip, ikan hiu juga dikomersialkan menjadi suplemen minyak ikan yang berasal dari organ hatinya yang memiliki kandungan vitamin A dan vitamin D (Hardiningsih et al. 2017). Banyaknya hasil produk olahan ikan hiu dapat menyebabkan ikan hiu menjadi satwa yang rentan akan kepunahan.

Ikan hiu memiliki ciri pertumbuhan kematangan reproduksi yang lambat, dengan periode kehamilan yang relatif lama (9-10 bulan) serta memiliki fekunditas yang rendah. Hal tersebut membuat populasinya rentan pada penangkapan ikan yang berlebihan (overfishing). Ancaman akan punahnya beberapa spesies hiu saat ini sudah mulai terjadi dan akan mengakibatkan populasinya menurun dalam habitatnya. Data hiu dan pari yang didaratkan secara global pada tahun 2003 menurun sebanyak 20\%, hal tersebut disebabkan karena adanya penurunan populasinya. Sebanyak 1038 spesies hiu dan pari yang termasuk termasuk dalam daftar International Union Conservation of Nature (IUCN) red list, terdapat 20 spesies yang dikategorikan sebagai Critically Endangered (CR), 45 spesies dikategorikan Endangered (EN), dan 116 spesies dikategorikan Vulnerable (VU), 127 spesies dikategorikan Near Threatened (NT) dan sisanya sebanyak 258 spesies berkategori Least Concern (LC) dan 472 spesies dikategorikan Data Deficient (DD) (Bräutigam et al. 2015). Pada saat ini terdapat delapan spesies ikan hiu yang masuk pada list data Apendiks II CITES (Convention on International Trade in Endangered Species). Delapan spesies ikan hiu yang terancam punah tersebut yaitu hiu paus (Rhincodon typus), hiu basking (Cetorhinus maximus), hiu putih (Carcharodon carcharias), hiu koboi (Carcharhinus longimanus), hiu martil (Sphyrna lewini), hiu martil halus (Sphyrna zygaena), hiu martil besar (Sphyrna mokarran) dan hiu porbeagle (Lamna nasus) (Fields et al. 2015). Peraturan izin ekspor perlu ditegakkan agar dapat teridentifikasi produk perikanan yang menggunakan spesies hiu dilindungi yang diperdagangkan secara global (Hellberg et al. 2019). Spesies hiu yang termasuk ke dalam data Apendiks II CITES saat dilakukan perdagangan internasional, perlu mengikuti peraturan yang ditetapkan oleh CITES, yaitu mengenai keberlanjutan (sustainability), keterlacakan (traceability) dan legalitas (KKP 2015). Ikan hiu perlu dibedakan lebih rinci agar dapat dibedakan antar spesiesnya. Hal tersebut dapat diketahui dengan cara mengidentifikasi jenis hiu yang digunakan dalam suatu produk.

Identifikasi jenis spesies hiu dapat dilakukan secara taksonomi oleh pakar taksonomi menggunakan indikator morfologi jika tampilan produk masih seperti seluruh tubuhnya. Kekurangan pengujian dari hal tersebut perlu pelatihan ekstensif dan adanya kemiripan tampilan spesies yang memiliki resiko kesalahan dalam penentuan spesies (Marshall dan Barone 2016). Masalah tersebut dapat diatasi dengan mengidentifikasi spesies ikan hiu menggunakan autentikasi berbasis biomolekuler menggunakan basa nukleotida atau Deoxyribonucleic Acid (DNA) yaitu DNA barcodes. Metode ini didasarkan pada penggunaan alat Polymerase Chain Reaction (PCR) untuk mengamplifikasi DNA universal atau spesifik pada suatu spesies (Hellberg et al. 2019). Metode analisis DNA barcodes merupakan metode untuk mengidentifikasi spesies dengan penggunaan urutan nukleotida sekuensingnya yang menunjukkan tingkat variasi yang cukup untuk membedakan antar spesies (Hartvig et al. 2015). Teknik ini memiliki kekurangan karena DNA full length dapat terdegradasi dan terfragmentasi pada proses olahan ekstensif (Shokralla et al. 2015). Sebagai metode alternatif untuk deteksi DNA spesies dalam produk yang sudah mengalami proses pengolahan dan berpotensi terdegradasi 
DNA-nya yaitu dengan teknik DNA mini barcodes.

Teknik DNA mini barcodes memfokuskan untuk menganalisis fragmen-fragmen DNA yang lebih pendek, yaitu pada 100-200 pb dalam DNA full length yang sama. Teknik ini terbukti efektif untuk memperoleh informasi mengenai urutan DNA dari spesimen produk olahan yang DNAnya telah terdegradasi. Informasi pengurutan gen fragmen yang memiliki barcode kecil $(\geq 100 \mathrm{pb})$ dapat memberikan informasi bagi identifikasi spesies dan memiliki keberhasilan lebih dari 90\% (Shokralla et al. 2015). Penelitian lain mengenai teknik DNA mini barcodes untuk ketelusuran label pangan berbagai produk olahan ikan sidat mendapatkan keberhasilan identifikasi kemiripan untuk spesies Anguilla bicolor bicolor sebesar 99-100\% dan Anguilla marmorata sebesar 100\% (Abdullah et al. 2018) serta untuk ketelusuran label pangan berbagai produk ikan layur berhasil teridentifikasi sebagai Trichiurus sp. dan T. lepturus dengan tingkat kemiripan 91-100\% (Abdullah et al. 2018). Abdullah et al. (2020) juga menggunakan DNA mini barcode untuk mengidentifikasi hiu yang diperdagangkan di pasar lokal Indonesia dengan sebagian besar sampel teridentifikasi sebagai Carcharhinus falciformis.

Penelitian menggunakan teknik DNA mini barcodes serta merancang primer spesies spesifik pada tiga species terdaftar CITES yang paling banyak didaratkan di Indonesia belum banyak dilakukan. Oleh sebab itu, perlu dilakukan penelitian mengenai autentikasi pada beberapa produk olahan ikan hiu menggunakan teknik DNA mini barcodes agar dapat dirancang dan diaplikasikan primer spesifiknya. Penelitian ini bertujuan untuk merancang dan mengaplikasikan primer DNA mini barcodes yang spesifik terhadap tiga species hiu terancam punah yang masuk dalam daftar CITES (Sphyrna lewini, Alopias pelagicus, Carcharhinus falciformis) serta mengaplikasikan pada berbagai produk olahan ikan hiu.

\section{Bahan dan Metode Bahan dan Alat}

Bahan baku yang digunakan adalah berbagai produk olahan yang diduga mengandung bahan baku ikan hiu. Sampel tersebut yaitu dua filet cucut beku dari pasar modern dan tradisional di Bogor yang berbeda (Fa dan $\mathrm{Fb}$ ), hiu asin (HA), hiu rebus (HR) dan gulai ikan hiu. Sampel lainnya merupakan hasil dari proses sampling di dua lokasi yaitu wilayah Aceh dan Nusa Tenggara Barat. Bahan lain yang digunakan meliputi KIT isolasi DNA (QIAGEN DNeasy Blood \& Tissue dan DNeasy Food and Mericon), KIT PCR (KAPA Taq PCR KITs, KapaBiosystems, Wilmington, AS), $\mathrm{ddH}_{2} \mathrm{O}$, primer spesifik Sphyrna lewini, Alopias pelagicus dan Carcharinus falciformis, primer universal DNA barcoding FishF1R1 (Ward et al. 2005), marker $100 \mathrm{pb}$ plus DNA ladder (VIVANTIS, Selangor Darul Ehsan, Malaysia), cybergeen, agarosa (SeaKem ${ }^{\circ} \mathrm{LE}$ Agarose, Lonza, Rockland, ME USA), buffer TBE (AccuGENETM 10X TBE Buffer, Lonza, Rockland, ME AS), EDTA 0.05\% dan $\mathrm{Na}_{2} \mathrm{CO}_{3}$ $0,2 \%$.

Alat yang digunakan meliputi kantung dialisis $(12 \mathrm{kDa})$, microtubes TUBE-150-C (Extragene, Taichung, Taiwan) dan tube PCR-02-C (Axygen, California, AS), pipet tips RC-10/20-L dan RC-250/20-C (Mettler Toledo, Bekasi, Indonesia), kantung dialysis $12 \mathrm{kDa}, 4$ micropipette 1-10 $\mu \mathrm{L}$, dan 20-200 $\mu \mathrm{L}$ (ThermoFisher Scientific, Vantaa, Finlandia), freezer, waterbath sonicator (BANDELIN electronic, Berlin, Jerman), vortex (V1-Plus, Biosan, Warren, AS), spin down (Corning, New York, USA), mikrosentrifugasi (Centurion Scientific 2041, Libertyville, AS), microwave (Sharp, Osaka, Jepang), timbangan digital (PHW 254, ADAM ${ }^{\circledR}$, Inggris), PCR (Applied Biosystem GeneAmp PCR System 9700, ThermoFisher Scientific, Vantaa, Finlandia), UV-Transilluminator (Uvitec, Cambridge, Inggris), elektroforesis horizontal (HU6, SCIEPLAS, Cambridge, Inggris), power supply (Peqlab, Erlangen, Jerman), dan nanodrop (Thermo Scientific, Vantaa, Jerman).

\section{Metode Penelitian}

Penelitian terbagi menjadi beberapa tahapan. Tahapanan tersebut yaitu preparasi sampel, desain primer spesifik ikan hiu $S$. lewini, A. pelagicus, C. falciformis, isolasi DNA untuk mendapatkan isolat DNA guna analisis 
kemurnian dan konsentrasinya, amplifikasi DNA menggunakan PCR, elektroforesis serta dilakukan tahap sekuensing. Hasil sekuen yang telah didapat dari masing-masing sampel dianalisis datanya menggunakan analisis bioinformatika.

\section{Isolasi DNA sampel olahan}

Sampel hiu dilindungi diisolasi dengan mengikuti prosedur kit komersil sesuai dengan jenis sampel. Isolasi DNA sampel produk olahan komersial ikan hiu dilakukan dengan menggunakan kit komersial Qiagen Dneasy Food Mericon untuk sampel yang telah mengalami pengolahan dan TiaNamp Genomic DNA kit untuk sampel yang ikan segar atau beku. Isolasi dengan Qiagen Dneasy Food Mericon kit menggunakan sampel sebanyak 0,2 g yang telah dihaluskan, sedangkan untuk sampel segar sebanyak 0,025 g.

\section{Amplifikasi DNA barcoding}

Amplifikasi DNA pada ruas gen COI dilakukan menggunakan teknik Polymerase Chain Reaction (PCR). Komponen-komponen yang digunakan pada proses PCR antara lain templat DNA, sepasang primer, ddH2O, master mix yang terdiri dari dNTP, buffer PCR, $\mathrm{MgCl} 2$, dan enzim polimerase. Master mix PCR dibuat dengan volume total $25 \mu \mathrm{L}$ yang terdiri dari $2 \mu \mathrm{L}$ template DNA, $8.5 \mu \mathrm{L}$ nucleas free water, $1 \mu \mathrm{L}$ primer forward, $1 \mu \mathrm{L}$ primer reverse, dan $12.5 \mu \mathrm{L}$ Taq polymerase. Kondisi suhu PCR pada sampel isolat menggunakan primer universal FishF1R1 pada tahap pre denaturation yaitu pada suhu $95^{\circ} \mathrm{C}$ selama 3 menit, tahap denaturation $95^{\circ} \mathrm{C}$ selama 30 detik, annealing pada $54^{\circ} \mathrm{C}$ selama 30 detik, extension pada $72^{\circ} \mathrm{C}$ selama 30 detik, dilanjutkan dengan final extension pada $72^{\circ} \mathrm{C}$ selama 5 menit (Ward et al. 2005). Primerprimer spesifik yang digunakan menggunakan kondisi PCR yang sama dengan primer FishF1R1 dengan perbedaan yaitu pada suhu annealing yang digunakan adalah $60^{\circ} \mathrm{C}$.

\section{Analisis Data}

Analisis bioinformatika dilakukan untuk menginterpretasikan data yang diperoleh. Analisis bioinformatika dilakukan menggunakan BLAST (Basic Local Alignment Search Tool) (Altschul et al. 1990) agar mendapat kemiripan spesies berdasarkan kemiripan urutan basa-basa nukleotida. Perbandingan urutan basa-basa nukleotida dibandingkan dengan basis data nucleotide references yang berasal dari GenBank (https://www.ncbi.nlm.nih.gov/nucleotide/). Penyejajaran sekuensing dilakukan untuk menentukan jarak genetik dan hubungan kekerabatan sampel yang dikonstruksi dengan pohon filogenetik menggunakan piranti lunak ClustalW yang terintegrasi pada software MEGA 5 (Molecular Evalutionary Genetic Analysis). Jarak genetik dihitung menggunakan metode pairwise distance dan rancangan pohon filogenetik (1.000 kali ulangan) dan metode neighbor-joining tree bootstrap model Kimura Two parameter (Kimura 1980).

\section{HASIL DAN PEMBAHASAN Konsentrasi dan Kemurnian Isolat DNA Sampel}

Analisis secara kuantitatif pada isolat DNA sampel agar dapat ditentukan kualitasnya berdasarkan konsentrasi dan kemurniannya. Kemurnian isolat DNA sampel diketahui dengan mempertimbangkan rasio absorbansi $\lambda_{260} / \lambda_{280}$. Hasil analisis kuantitatif isolat DNA dapat dilihat pada Table 1.

Nilai konsentrasi isolat DNA tertinggi terdapat pada sampel hiu rebus (HR) yaitu $108.4 \mathrm{ng} / \mu \mathrm{L}$ dan konsentrasi terkecil terdapat pada sampel daging hiu S. lewini (SL) dengan nilai $8.9 \mathrm{ng} / \mu \mathrm{L}$. Nilai konsentrasi DNA bergantung pada tahap proses isolasi DNA yaitu saat pemecahan sel untuk mengeluarkan DNA. Proses pengolahan produk berupa pemanasan dan penambahan bumbu-bumbu dapat memberi efek terjadinya degradasi DNA saat proses pengolahan. Konsentrasi dari sampel HA yang tidak terlalu tinggi dapat disebabkan adanya efek dari proses penggaraman dan pengeringan ikan yang bertujuan mengawetkan produk makanan. Konsentrasi dari sampel $\mathrm{Fa}, \mathrm{Fb}$ dan SL yang rendah dapat disebabkan oleh jenis kit isolasi DNA yang digunakan maupun kesalahn teknis pada saat proses isolasi. Tagliavia et al. (2016) menambahkan bahwa analisis DNA 
Table 1 DNA Concentration of Shark's seafood products

\begin{tabular}{lrr}
\hline Samples & $\begin{array}{r}\text { DNA Concentration } \\
(\mathrm{ng} / \mu \mathrm{L})\end{array}$ & $\begin{array}{c}\text { DNA Purity } \\
(\mathrm{A} 260 / \mathrm{A} 280)\end{array}$ \\
\hline F1 & 12.6 & 2.01 \\
$\mathrm{~F} 2$ & 21.6 & 1.96 \\
$\mathrm{HA}$ & 12.1 & 1.22 \\
$\mathrm{HR}$ & 108.4 & 1.69 \\
SL & 8.9 & 1.95 \\
$\mathrm{~A}$ & 26.8 & 1.81 \\
SL1 & 41.1 & 1.82 \\
SL2 & 41.5 & 1.87 \\
AP4 & 11.75 & 1.70 \\
CF3 & 13.35 & 2.09 \\
B & 76.70 & 1.91 \\
\hline Note: F1= fillet A, F2= fillet B, HA= Salted fish, HR= Boiled fish, \\
SL= S. Lewini, CF = Carcharinus falciformis; B = Fish Gulai
\end{tabular}

dari produk olahan laut, dapat mengalami degradasi DNA dan adanya inhibitor akibat proses pengolahan produk makanan berupa senyawa fenol maupun polisakarida. Hasil isolat DNA dengan konsentrasi dan kemurnian yang rendah, dapat mempengaruhi proses selanjutnya yaitu amplifikasi dengan PCR.

Hasil kemurnian DNA dari keseluruhan sampel menunjukkan kisaran dari 1,22 hingga 2,01. Sampel isolat DNA pada hiu asin (HA) dan hiu rebus (HR) memiliki kemurnian DNA berturut-turut 1,22 dan 1,69. Hasil tersebut menunjukkan adanya kontaminan pada isolat DNA berupa protein dan polisakarida sehingga relatif kurang murni. Proses kontaminasi dapat terjadi akibat teknik memipet yang kurang sempurna sehingga pengotor masih terbawa. Tagliavia et al. (2016) menambahkan bahwa pemurnian isolat DNA diperlukan karena beberapa bahan kimia yang digunakan pada langkah isolasi DNA dapat menghambat proses amplifikasi dan akan mempengaruhi ukuran amplikon.

Kemurnian DNA dinilai baik jika berada pada rentang 1.8 - 2.0 pada rasio absorbansi $\lambda_{260} / \lambda_{280}$ (Sambrook dan Russel 2001). Nilai rasio absorbansi $\lambda_{260} / \lambda_{280}$ yang berada $<1.8$ menandakan terdapatnya kontaminan berupa protein dan polisakarida. Nilai rasio absorbansi $\lambda_{260} / \lambda_{280}$ yang berada $>2.0$ menandakan masih terdapatnya kontaminan berupa RNA (Khosravinia et al. 2007).

\section{Amplikon DNA Produk Olahan Perikanan}

Proses amplifikasi pada penelitian ini menggunakan dua jenis primer, yaitu primer universal dan primer spesifik terhadap tiga species ikan hiu terdaftar CITES. Hasil visualisasi dari produk PCR spesifik (amplifikasi sampel) dapat dilihat pada Figure 1.

Figure 1 (a) menunjukkan hanya sampel HR dan SL saja yang berhasil teramplifikasi, yaitu pada rentang $500-700$ pb sedangkan sampel F1, F2 dan HA tidak berhasil teramplifikasi. Figure 1(b) elektroforegram sampel SL, HR dan HA telah sesuai dengan gen target pada primer spesifik S. lewini yaitu $279 \mathrm{pb}$ yang berada dibawah $500 \mathrm{pb}$. Sampel lainnya yaitu F1 dan F2 pada gambar elektroforegram tidak teramplifikasi pada target yang ditentukan. Shokralla et al. (2015) menambahkan bahwa penyebab kegagalan penggunaan primer full length barcode ialah DNA sampel telah terdegradasi dari saat proses pengolahan yang menggunakan tahapan proses ekstensif dan berbagai macam tambahan bahan aditif sehingga mempersulit DNA untuk dilakukan isolasi. Shokralla et al. (2015) menambahkan bahwa DNA yang telah terdegradasi akan menghambat proses amplifikasi. 
Penyebab kegagalan amplifikasi lainnya adalah keberadaaan primer dimer yang merupakan proses penempelan primer menempel pada primer lainnya yang dianggap sebagai template saat proses amplifikasi (Sasmito et al. 2014). Popa et al. (2007) menambahkan bahwa hasil amplifikasi yang tidak spesifik akan menyebabkan terbentuknya primer dimer yang mendakan kurangnya keberhasilan dalam reaksi. Kurangnya keberhasilan dari amplifikasi ini karena masih terbawanya kontaminan berupa protein atau sel lain yang berasal dari isolat DNA.

Figure 1 (c) dan (d) menunjukkan panjang amplikon untuk sampel AP berada pada rentang 200-300 bp, sedangkan sampel CF berada pada rentang antara 300-400 bp. Hasil tersebut telah sesuai dengan panjang amplikon untuk primer spesifik mini barcode masing-masing hiu $A$. pelagicus dan $C$. falciformis yaitu 285 bp dan 352 bp. Hasil produk PCR dengan primer spesifik mini

(a)

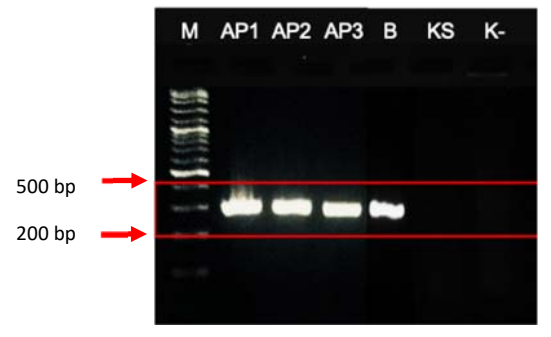

(c)
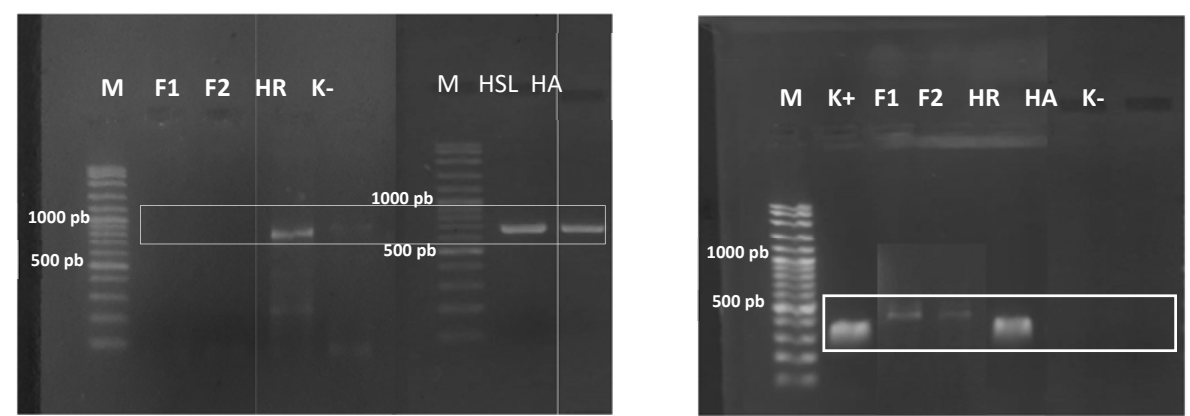

Figure 1 PCR products electropherogram: (a) universal DNA barcoding primer results, (b) Sphyrna lewini's species specific primer, (c) Alopias pelagicus's species specific primer, (d) Carcharinus falciformis's species specific primer. Note: $\mathrm{M}=$ marker, F1: frozen fillet A, F2: frozen fillet B, HSL: S. lewini: HA: Salted fish, HR: Boiled fish meat, AP 1-3: Alopias pelagicus with triplicate replication,

CF: Carcharhinus falciformis with triplicate replication; K-: negative control.

KS: H Hemigaleus microstoma as an outgrup. 
Table 2 Species identification results by BLAST dan BOLD

\begin{tabular}{llrrl}
\hline $\begin{array}{c}\text { Sample's } \\
\text { Code }\end{array}$ & \multicolumn{1}{c}{ Species ID } & Homology & E value & Access code \\
\hline \multicolumn{1}{c}{ BLAST NCBI } \\
HR & Sphyrna lewini & $99 \%$ & 0.0 & JX827259.1 \\
SL & Sphyrna lewini & $98 \%$ & 0.0 & JX827259.1 \\
HA & Hemigaleus microstoma & $99 \%$ & 0.0 & NC0229400.1 \\
CF3 & Carcharhinus falciformis & $100 \%$ & $5 \mathrm{e}-140$ & MT357187.1 \\
AP4 & Alopias pelagicus & $100 \%$ & $3 \mathrm{e}-106$ & KF020876.1 \\
B & Alopias pelagicus & $100 \%$ & $8 \mathrm{e}-107$ & KF020876.1 \\
\hline & & BOLD Systems & & \\
\hline HR & Sphyrna lewini & $100 \%$ & - & KP719756 \\
SL & Sphyrna lewini & $99.83 \%$ & - & KP719760 \\
HA & Hemigaleus microstoma & $99.62 \%$ & - & EU398811 \\
CF3 & Carcharhinus falciformis & $100 \%$ & - & GBGC19796-19 \\
AP4 & Alopias pelagicus & $100 \%$ & - & GBGC10637-13 \\
B & Alopias pelagicus & $100 \%$ & - & GBGC10637-13 \\
\hline
\end{tabular}

komposisi primer yang tidak tepat juga dapat menyebabkan kegagalan amplifikasi sehingga terbentuk primer dimer atau struktur sekunder lain yang tidak diinginkan. Primer dimer ditunjukkan dengan terbentuknya pita DNA pada bagian dasar sumur sampel gel agarose (Lorenz et al. 2012). Primer dimer dapat disebabkan karena tingginya konsentrasi primer yang digunakan. Kondisi PCR terutama proses annealing menjadi salah satu tahap yang menentukan keberhasilan proses PCR, sehingga optimasi suhu annealing sangat diperlukan. Suhu annealing ditentukan berdasarkan nilai suhu leleh melalui proses optimasi. Nilai Tm antara sepasang primer dihitung berdasarkan rata-rata suhu leleh primer reverse dan primer forward.

\section{Bioinformatika Sekuen DNA Sampel}

Pita DNA dari produk PCR yang berhasil dilihat visualisasinya menggunakan gel elektroforesis kemudian dibuktikan dengan proses sekuensing. Sampel yang dilakukan sekuensing yaitu sampel hiu rebus (HR) dan sampel hiu S. lewini (SL) dan sampel hiu asin (HA) yang pada tahap PCR didapat pita DNA yang baik dan tidak terdapat dimer atau smear. Hasil sekuens yang diterima dibandingkan dengan data spesies pada GenBank di NCBI dengan menggunakan BLAST dan Barcoding of Life Data (BOLD) System kemudian diperoleh tingkat identitasnya. Hasil identifikasi spesies dapat dilihat pada Table 2.

Table 2 menunjukkan hasil analisis bioinformatika dengan menggunakan BLAST dan Barcoding of Life Data (BOLD) System. BOLD merupakan database terbesar untuk identifikasi spesies ikan dari gen COI. Korelasi persamaan antara BLAST dan BOLD yang memiliki GenBank database untuk gen fragment COI yaitu 99\% hingga 100\%. Hasil analisis sekuensing menunjukkan bahwa sampel hiu asin (HA) teridentifikasi sebagai sicklefin weasel shark yang memiliki nama ilmiah Hemigaleus microstoma dengan kemiripan sebesar 99\% dari BLAST NCBI dan $99.62 \%$ dari BOLD Systems. Sampel hiu rebus (HR) dan sampel hiu S.lewini Lombok (SL), spesifik pada jenis ikan hiu martil dengan nama ilmiah Sphyrna lewini. Tingkat kemiripan dari sampel hiu rebus didapat sebesar 99\% dari BLAST NCBI dan 100\% dari BOLD Systems. Hasil autentikasi yang menunjukkan spesies hiu martil (Sphyrna lewini) termasuk dalam daftar IUCN red list yang terancam punah (endangered).

Sampel hiu S. lewini Lombok (SL) memiliki tingkat kemiripan sebesar 98\% dari 
BLAST NCBI dan 99,83\% dari BOLD Systems. Sampel CF berdasarkan hasil analisis BLAST maupun BOLD sistem teridentifikasi sebagai Carcharhinus falciformis dengan tingkat kemiripan 100\%, sedangkan sampel AP dan B teridentifikasi sebagai Alopias pelagicus dengan tingkat kemiripan $100 \%$. Berdasarkan hasil tingkat kemiripan dari masing-masing sampel yang disekuensing maka dapat disimpulkan bahwa semua sampel SL, AP, dan CF yang digunakan dalam penelitian merupakan spesies hiu Sphyrna lewini, Alopias pelagicus, dan Carcharhinus falciformis. Hasil sekuensing juga menunjukkan bahwa primer mini barcode yang telah dirancang mampu mengamplifikasi sampel secara spesifik. Tingkat kemiripan merupakan persentase kesamaan suatu sekuen dengan data yang tersedia di bank data. Persentasi tingkat kemiripan sekuen dengan repository apabila mencapai $97-100 \%$ dikatakan signifikan, 92\% hingga 96\% dikatakan cukup dan lebih kecil dari $91 \%$ dikatakan tidak signifikan (Bhattacharjee et al. 2012).

Nilai Expect value (E. value) pada seluruh sampel yang diidentifikasi yaitu sebesar 0 . Drancourt et al. (2000) menyatakan bahwa tingkat kemiripan yang berada pada nilai lebih dari 99\% menunjukkan kecocokan antar perbandingan antar spesies, tingkat kemiripan lebih dari $97 \%$ menunjukkan kecocokan perbandingan antar genus dan tingkat kemiripan pada rentang $89-93 \%$ menunjukkan perbedaan kecocokan antar famili. Hasil E-value bernilai 0 memiliki perbandingan spesies identik. Claveire dan Notredame (2007) menyatakan bahwa nilai E.value merupakan ukuran nilai kecocokan yang terjadi antara sekuens dengan database pada GenBank.

\section{KESIMPULAN}

Penggunaan primer spesifik mini barcodes memiliki hasil yang baik pada sampel produk olahan yang diduga merupakan daging ikan hiu. Hasil sekuensing produk PCR dengan seluruh primer mini barcode yang telah dirancang mampu mengamplifikasi secara spesifik dan telah sesuai dengan rancangan in silico. Hasil identifikasi dari beberapa produk hiu menunjukkan spesies tersebut termasuk dalam daftar IUCN red list yang terancam punah (endangered).

\section{UCAPAN TERIMA KASIH}

Penulis mengucapkan terima kasih kepada Kementerian RISTEK-BRIN untuk pembiayaan penelitian ini melalui hibah Penelitian Terapan (PT) T.A 2020 dengan nomor kontrak 1/AMD/E1.KP.PTNBH/2020. Penulis juga mengucapkan terimakasih kepada tim WCS Indonesia yang sudah membantu menyediakan sampel produk olahan hiu.

\section{DAFTAR PUSTAKA}

Abdullah A, Nurilmala M, Muttaqin E, Yulianto I. 2020. DNA-based analysis of shark products sold on the Indonesian market toward seafood labelling accuracy program. Biodiversitas. 21(4): 1385-1390.

Abdullah A, Nurilmala M, Sari AS, Jacoeb AM. 2018. Mini-COI barcodes sebagai penanda molekuler untuk ketertelusuran label pangan berbagai produk olahan ikan sidat. Jurnal Pengolahan Hasil Perikanan Indonesia. 21(2): 377 - 384.

Abdullah A, Nurilmala M, Sitaresmi KP. 2018. DNA mini-barcodes sebagai penanda molekuler untuk ketertelusuran label pangan berbagai produk ikan layur. JPHPI. 22(1): 33 - 40.

Altschul, S.F., Gish, W., Miller, W., Myers, E.W. \& Lipman, D.J. (1990) "Basic local alignment search tool." J. Mol. Biol. 215:403-410.

Bhattacharjee MJ, Laskar BA, Dhar B, Ghosh SK. 2012. Identification and re-evoluation of freshwater catfishes through DNA barcoding. Plos One. 7: 1-7.

Bräutigam A, Callow M, Campbell IR, Camhi MD, Cornish AS, Dulvy NK, Fordham SV, Fowler SL, Hood AR, McClennen C, Reuter EL, Sant G, Simpfendorfer CA, Welch DJ. 2015. Global Priorities for Conserving Sharks and Rays: A 2015-2025 Strategy. San Jose (CR): Copa.

Claveire JM, Notredame C. 2007. Bioinformatics for Dummies $2^{\text {nd }}$ Edition. Indianapolis (US): Wiley Publishing.

Damayanti IAM, Junitha IK, Suaskara IBM. 2014. Variasi genetik soroh brahmana budha di Bali berdasarkan penanda DNA 
mikrosatelit kromosom-Y. Jurnal Biologi. 18(2): 46-51.

Drancourt M, Bollet C, Carlioz A, Martelin R, Gayral JP, Raoult D. 2000. 16s Ribosomal DNA sequence analysis of a large collection of environmental and clinical unidentifiable barcterial isolats. Journal of Clinical Microbiology. 33(10): 3623-3630.

Fields AT, Abercrombie DL, Eng R, Feldheim K, Chapman DD. 2015. A novel minidna barcoding assay to identify processed fins from internationally protected shark species. Plos One. 10(2): 1 - 10.

Hardiningsih W, Purwadi H, Latifah E. 2017. Dampak ketiadaan pengaturan kuota ekspor hiu tikus (Alopias sp.) di Indonesia. Padjajaran Journal of Law. 4(3): $588-605$.

Hartvig I, Czako M, Kjær ED, Nielsen LR, Theilade I. 2015. The use of DNA barcoding in identification and conservation of rosewood (Dalbergia spp.). Plos One. 10(9): 1-24.

Hellberg RS, Isaacs RB, Hernandez EL. 2019. Identification of shark species in commercial products using DNA barcoding. Journal Fisheries Research. 210(1): $81-88$

Khosravinia H, Murthy HNN, Parasad DT, Pirany M. 2007. Optimizing factors influencing DNA extraction from fresh whole avian blood. African Journal of Biotechnology. 6(4): 481-486.

Kimura M. 1980. A simple method for estimating evolutionary rate of base substitutions through comparative studies of nucleotide sequences. Journal of Molecular Evolution. 16(2):111- 120.

[KKP] Kementrian Kelautan dan Perikanan. 2015. Pedoman Identifikasi dan Pendataan Hiu Apendiks II CITES. Jakarta: Kementrian Kelautan dan Perikanan.

Lorenz TC. 2012. Polymerase chain reaction:
Basic protocol plus troubleshooting and optimization strategies. Journal of Visualized Experiments. 63(5): 1-15.

Marshall LJ, Barone M. 2016. SharkFin Guide: Identifying Sharks from Their Fins. Roma (IT): FAO.

Popa OP, Murariu D, Popa LO. 2007. Comparison of four DNA extraction methods from invasive freshwater bivalve species in Romanian Fauna. Gigore Entipa. 50(6): 527-539.

Sambrook J, Russell DW. 2001. Molecular Cloning: a Laboratory Manual 3rd Edition. New York (USA): Cold Spring Harbor.

Sasmito DEK, Kurniawan R, Muhimmah I. 2014. Karakteristik primer pada Polymerase Chain Reaction (PCR) untuk sekuensing DNA: mini review. Seminar Nasional Informatika Medis (SNIMed). 5(1): 93-102.

Shokralla S, Hellberg RS, Handy SR, King I, Hajibabei M. 2015. A DNA minibarcoding system for authentication of processed fish products. Science Reports. 5(1): $1-11$.

Tagliavia M, Nicosia A, Salamone M, Biondo G, Bennici CD, Mazzola S, Cuttitta A. 2016. Development of a fast DNA extraction method for sea food and marine species identification. Food Chemistry. 203(3): 375-378.

Wallace LJ, Boilard SMAL, Eagle SHC, Spall JL, Shokralla S, HAjibabei M. 2012. DNA barcodes for everyday life: routine authentication of natural health products. Food Research International 49(1): 446452.

Ward RD, Zemlak TS, Innes BH, Last PR, Hebert PDN. 2005. DNA barcoding Australia's fish species. Philosophical Transactions of The Royal Society B. 360(1): 1847-1857. 